\section{Nauplius}

The Journal of The

Brazilian Crustacean Society

e-ISSN 2358-2936

www.scielo.br/nau www.crustacea.org.br
This article is part of the tribute offered

by the Brazilian Crustacean Society

in memoriam of Michael Türkay

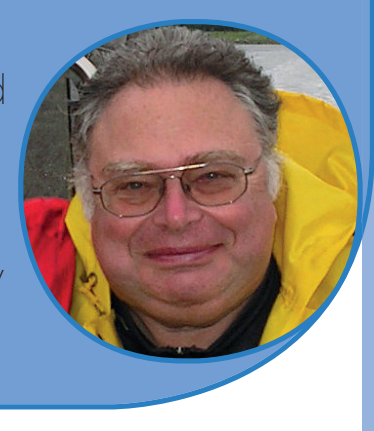

Original Article

\title{
New records and bathymetric distribution of deep-sea shrimps of the family Glyphocrangonidae (Decapoda: Caridea) from the Potiguar Basin, northeastern Brazil
}

Flavio de Almeida Alves-Júnior ${ }^{1}$, Marina de Sá Leitão Câmara de Araújo ${ }^{2}$ and Jesser F. Souza-Filho'

\footnotetext{
${ }^{1}$ Laboratório de Carcinologia, Museu de Oceanografia da Universidade Federal de Pernambuco (UFPE). Av. Arquitetura, s/n, Cidade Universitária. Recife, Pernambuco, Brazil.

2 Coleção Didática de Zoologia da UPE, Faculdade de Ciências, Educação e Tecnologia de Garanhuns, Universidade de Pernambuco (UPE). Rua Capitão Pedro Rodrigues, 105, São José. Garanhuns, Pernambuco, Brazil.
}

ZOOBANK http://zoobank.org/urn:1sid:zoobank.org:pub:485A4179-CA6B-4176A416-2A4CDCEFB58F

CORRESPONDING AUTHOR Flavio de Almeida Alves-Júnior bioflavio@hotmail.com

SUBMITTED 10 June 2016 ACCEPTED 21 September 2016 PUBLISHED 6 April 2017

Guest Editor

Célio Magalhães

\section{AbSTRACT}

The caridean family Glyphocrangonidae Smith, 1884 is monotypic, including only the genus Glyphocrangon A. Milne-Edwards, 1881. The species of this genus are exclusively inhabitants of deep sea. The current contribution aims to enrich the knowledge of Glyphocrangon in the southwestern Atlantic, by reporting its occurrence and bathymetric distribution in the Potiguar Basin, northeastern Brazil. The samples were collected by R/V Luke Thomas and $\mathrm{R} / \mathrm{V}$ Seward Johnson, with bottom trawling at isobaths of 400, 1,000 and 2,000 m, using an otter trawl semi-balloon. The specimens were identified and stored in the carcinological collection of the Museu de Oceanografia Prof. Petrônio Alves Coelho, in Recife, Brazil. A total of 810 specimens were examined from five species: Glyphocrangon aculeata A. Milne-Edwards, 1881, G. alispina Chace, 1939, G. longirostris (Smith, 1882), G. sculpta (Smith, 1882) and G. spinicauda A. Milne-Edwards, 1881. Glyphocrangon spinicauda 
was the most abundant with 334 individuals, and G. sculpta was the rarest, with only one individual. All species were recorded in the study area for the first time.

\section{KEY WORDS}

Continental slope, geographical distribution, Glyphocrangon, new occurrences, South Atlantic.

\section{INTRODUCTION}

Knowledge of deep-sea crustaceans in the southwestern Atlantic is still scarce, mainly due to logistic difficulties and the high cost for obtaining samples (Ramos-Porto et al., 2000). However, some previous studies have contributed to our knowledge on decapod crustaceans inhabiting the continental slope to abyssal basin regions, e.g., D’Incao (1998), Ramos-Porto et al. (2000; 2003), Coelho et al. (2006), Komai (2004a), Cardoso (2006; 2010a; 2010b; 2011a; 2011 b; 2013), Cardoso and Serejo (2007), Rego and Cardoso (2010), Cardoso and Fransen (2012), Anker et al. (2014), and Cardoso et al. (2014). These studies largely focused on taxonomic and distributional aspects, although the total inventory of the fauna is still far from complete.

The caridean family Glyphocrangonidae Smith, 1884 is monotypic, comprised of only the genus Glyphocrangon A. Milne-Edwards, 1881. Currently, 89 species of this genus have been recorded worldwide, inhabiting exclusively muddy bottoms in continental slope and abyssal plains as deep as 6,373 $\mathrm{m}$ (Holthuis, 1971; Rice, 1981; Chace, 1984; Kensley et al., 1987; Burukovsky, 1990; 2004; Komai and Takeuchi, 1994; Brand and Takeda, 1996; Komai, 2004a; 2004b; 2005; 2006; 2007; 2010; 2011; Komai and Chan, 2008; 2013; Hendrickx, 2010; De Grave and Fransen, 2011). In the western Atlantic, along the Brazilian coast, eight species of Glyphocrangon have previously been recorded from off Amapá to São Paulo (Komai, 2004a).

Recently, the project "Avaliação da biota bentônica e planctônica da Bacia Potiguar e Ceará (Bpot)", sponsored by the oil company "Petróleo Brasileiro S/A (Petrobrás)", was conducted off the states of Rio Grande do Norte and Ceará, northeastern Brazil, as part of a monitoring program of the oil extraction area. This contribution reports the taxonomic composition, geographic distribution and ecological aspects of species of Glyphocrangonidae collected during the monitoring activities in the Potiguar Basin.

\section{Material and Methods}

The Potiguar Basin, situated in the extreme northeast of Brazil, between the states of Rio Grande do Norte (RN) and Ceará (CE) (Fig. 1), belongs to a group of mesocenozoic basins that form the coastal province of the Brazilian continental margin. It comprises approximately $38,500 \mathrm{~km}^{2}$, distributed between the continental shelf and the continental slope, to the depth of 2,000 m (Bertani et al., 1990; Alves-Júnior et al., 2016a, b).

The samplings were carried out from the R/V Luke Thomas in 2009 "Arrasto Malha Talude" (AR and ARMT samples) and from the R/V Seward Johnson in 2011 "Malha Talude" (MT samples). Bottom trawls of an approximately 30 minutes duration were conducted on the continental slope along the isobaths of 400 $\mathrm{m}, 1,000 \mathrm{~m}$ and 2,000 $\mathrm{m}$, using a semi-balloon otter trawl with $50 \mathrm{~mm}$ mesh size and $18 \mathrm{~m}$ opening. The specimens were preserved in $70 \%$ ethanol.

In the laboratory, the specimens were sorted and identified following Holthuis (1971) and Komai (2004a). The morphological diagnosis of each species can be found in Komai (2004a). All material was deposited in the Carcinological Collection of the "Museu de Oceanografia Prof. Petrônio Alves Coelho (MOUFPE)" at the "Universidade Federal de Pernambuco", Recife, Brazil. The station, date, geographic coordinates, depths, temperature and salinity of each sampling station are presented in Tab. 1 . The material examined is presented as follows: total number of individuals (IN); sex [males (M), females (F), ovigerous females (OF) ], campaign (Bpot-Talude), station (ARMT; AR; MT) and catalogue number (MOUFPE). Total and carapace lengths (without rostrum) (TL and CL, respectively) were measured to the nearest $0.1 \mathrm{~mm}$ and minimum, maximum and mean values are provided in Tab. 2. The terminology follows Holthuis (1971). 


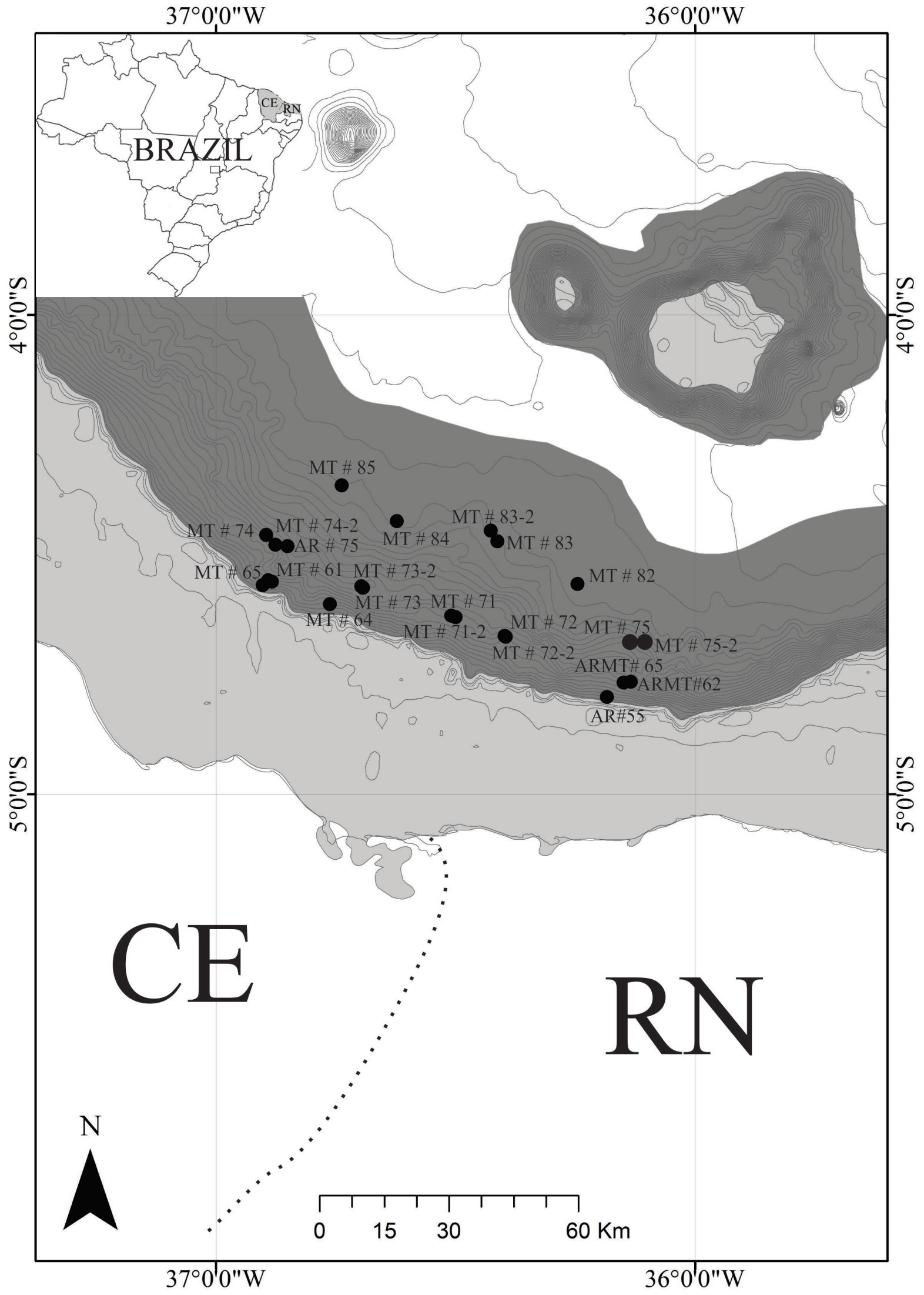

Figure 1. Location of the sampling stations between the states of Rio Grande do Norte and Ceará, northeast of Brazil. 
Table 1. Stations list for the species of Glyphocrangon A. Milne-Edwards, 1881 with station number, sampling date, locality, initial and final coordinates of the trawl, initial and final depth of trawl and depth in the Potiguar Basin, northeastern Brazil.

\begin{tabular}{|c|c|c|c|c|c|c|c|c|c|}
\hline Station & Date & Locality & $\begin{array}{l}\text { Trawl Initial } \\
\text { Coordinates }\end{array}$ & $\begin{array}{l}\text { Trawl Final } \\
\text { Coordinates }\end{array}$ & $\begin{array}{l}\text { Initial } \\
\text { Depth }\end{array}$ & $\begin{array}{l}\text { Final } \\
\text { Depth }\end{array}$ & Isobath & $\begin{array}{c}\text { Temperature } \\
{ }^{\circ} \mathbf{C}\end{array}$ & Salinity \\
\hline ARMT- 62 & 08.xii.2009 & Bpot- Talude & $\begin{array}{c}04^{\circ} 33^{\prime \prime} .21^{\prime} \mathrm{S} / \\
036^{\circ} 53^{\prime \prime} .452^{\prime} \mathrm{W}\end{array}$ & $\begin{array}{l}04^{\circ} 33^{\prime \prime} .5862^{\prime} \mathrm{S} / \\
036^{\circ} 52^{\prime \prime} .0435^{\prime} \mathrm{W}\end{array}$ & $389 \mathrm{~m}$ & $480 \mathrm{~m}$ & $400 \mathrm{~m}$ & 8.71 & 34.70 \\
\hline ARMT - 65 & 08.xii.2009 & Bpot- Talude & $\begin{array}{l}04^{\circ} 33.21^{\prime} \mathrm{S} / \\
036^{\circ} 53.45^{\prime} \mathrm{W}\end{array}$ & $\begin{array}{l}04^{\circ} 33.58^{\prime} \mathrm{S} / \\
036^{\circ} 52.04^{\prime} \mathrm{W}\end{array}$ & $389 \mathrm{~m}$ & $480 \mathrm{~m}$ & $400 \mathrm{~m}$ & 8.32 & 34.66 \\
\hline AR- 75 & 08.xii.2009 & Bpot- Talude & $\begin{array}{l}04^{\circ} 27.56^{\prime} \mathrm{S} / \\
036^{\circ} 53.72^{\prime} \mathrm{W}\end{array}$ & $\begin{array}{l}04^{\circ} 28.84^{\prime} \mathrm{S} / \\
036^{\circ} 50.89^{\prime} \mathrm{W}\end{array}$ & $1068 \mathrm{~m}$ & $996 \mathrm{~m}$ & $1000 \mathrm{~m}$ & 4.14 & 34.46 \\
\hline MT- 61 & 08.v.2011 & Bpot- Talude & $\begin{array}{l}04^{\circ} 47.8374^{\prime} \mathrm{S} / \\
036^{\circ} 11.0289^{\prime} \mathrm{W}\end{array}$ & $\begin{array}{l}04^{\circ} 48.1933^{\prime} \mathrm{S} / \\
036^{\circ} 9.6490^{\prime} \mathrm{W}\end{array}$ & $418 \mathrm{~m}$ & $457 \mathrm{~m}$ & $400 \mathrm{~m}$ & 8.15 & 34.66 \\
\hline MT- 64 & 12.v.2011 & Bpot- Talude & $\begin{array}{l}04^{\circ} 36.2400^{\prime} \mathrm{S} / \\
036^{\circ} 45.7395^{\prime} \mathrm{W}\end{array}$ & $\begin{array}{l}04^{\circ} 36.5247^{\prime} \mathrm{S} / \\
036^{\circ} 44.5867^{\prime} \mathrm{W}\end{array}$ & $416 \mathrm{~m}$ & $410 \mathrm{~m}$ & $400 \mathrm{~m}$ & 7.47 & 34.60 \\
\hline MT- 65 & 13.v.2011 & Bpot- Talude & $\begin{array}{l}04^{\circ} 33.3976^{\prime} \mathrm{S} / \\
036^{\circ} 52.9938^{\prime} \mathrm{W}\end{array}$ & $\begin{array}{l}\text { S } 04^{\circ} 33.7317^{\prime} / \\
\text { W } 036^{\circ} 51.7720^{\prime}\end{array}$ & $390 \mathrm{~m}$ & $480 \mathrm{~m}$ & $400 \mathrm{~m}$ & 8.58 & 34.70 \\
\hline MT- 71 & 05.v.2011 & Bpot- Talude & $\begin{array}{l}04^{\circ} 46.0360^{\prime} \mathrm{S} / \\
036^{\circ} 8.9450^{\prime} \mathrm{W}\end{array}$ & $\begin{array}{l}04^{\circ} 46.2246^{\prime} \mathrm{S} / \\
036^{\circ} 8.0126^{\prime} \mathrm{W}\end{array}$ & $937 \mathrm{~m}$ & $1074 \mathrm{~m}$ & $1000 \mathrm{~m}$ & 4.30 & 34.47 \\
\hline MT 71-2 & 20.v.2011 & Bpot- Talude & $\begin{array}{l}\text { S } 04^{\circ} 45.9390^{\prime} / \\
\text { W } 036^{\circ} 8.0415^{\prime}\end{array}$ & $\begin{array}{c}04^{\circ} 45.6749^{\prime} \mathrm{S} / \\
036^{\circ} 3808^{\prime} \mathrm{W}\end{array}$ & $1040 \mathrm{~m}$ & $1110 \mathrm{~m}$ & $1000 \mathrm{~m}$ & 4.30 & 34.47 \\
\hline MT- 72 & 07.v.2011 & Bpot- Talude & $\begin{array}{l}04^{\circ} 40.1817^{\prime} \mathrm{S} / \\
036^{\circ} 23.8647^{\prime} \mathrm{W}\end{array}$ & $\begin{array}{l}04^{\circ} 40.9363^{\prime} \mathrm{S} / \\
036^{\circ} 22.7249^{\prime} \mathrm{W}\end{array}$ & $908 \mathrm{~m}$ & $897 \mathrm{~m}$ & $1000 \mathrm{~m}$ & 4.25 & 34.45 \\
\hline MT- 72-2 & 20.v.2011 & Bpot- Talude & $\begin{array}{l}04^{\circ} 40.2981^{\prime} \mathrm{S} / \\
036^{\circ} 23.7001^{\prime} \mathrm{W}\end{array}$ & $\begin{array}{l}04^{\circ} 41.2780^{\prime} \mathrm{S} / \\
036^{\circ} 22.1763^{\prime} \mathrm{W}\end{array}$ & $960 \mathrm{~m}$ & $1062 \mathrm{~m}$ & $1000 \mathrm{~m}$ & 4.25 & 34.45 \\
\hline MT- 73 & 05.v.2011 & Bpot- Talude & $\begin{array}{l}04^{\circ} 37.6640^{\prime} \mathrm{S} / \\
036^{\circ} 30.5400^{\prime} \mathrm{W}\end{array}$ & $\begin{array}{l}04^{\circ} 38.1020^{\prime} \mathrm{S} / \\
036^{\circ} 29.4490^{\prime} \mathrm{W}\end{array}$ & $957 \mathrm{~m}$ & $938 \mathrm{~m}$ & $1000 \mathrm{~m}$ & 4.20 & 34.54 \\
\hline MT 73-2 & 16.v.2011 & Bpot- Talude & $\begin{array}{l}04^{\circ} 37.8519^{\prime} \mathrm{S} / \\
036^{\circ} 30.0082^{\prime} \mathrm{W}\end{array}$ & $\begin{array}{l}04^{\circ} 38.6087^{\prime} \mathrm{S} / \\
036^{\circ} 28.1616^{\prime} \mathrm{W}\end{array}$ & $955 \mathrm{~m}$ & $1006 \mathrm{~m}$ & $1000 \mathrm{~m}$ & 4.20 & 34.54 \\
\hline MT- 74 & 07.v.2011 & Bpot- Talude & $\begin{array}{l}04^{\circ} 34.1484^{\prime} \mathrm{S} / \\
036^{\circ} 41.6035^{\prime} \mathrm{W}\end{array}$ & $\begin{array}{l}04^{\circ} 33.9360^{\prime} \mathrm{S} / \\
036^{\circ} 40.6900^{\prime} \mathrm{W}\end{array}$ & $902 \mathrm{~m}$ & $1073 \mathrm{~m}$ & $1000 \mathrm{~m}$ & 4.23 & 34.52 \\
\hline MT 74-2 & 15.v.2011 & Bpot- Talude & $\begin{array}{l}04^{\circ} 33.9768^{\prime} \mathrm{S} / \\
036^{\circ} 41.8026^{\prime} \mathrm{W}\end{array}$ & $\begin{array}{l}04^{\circ} 35.2912^{\prime} \mathrm{S} / \\
036^{\circ} 43.3197^{\prime} \mathrm{W}\end{array}$ & $987 \mathrm{~m}$ & $1080 \mathrm{~m}$ & $1000 \mathrm{~m}$ & 4.23 & 34.52 \\
\hline MT- 75 & 03.v.2011 & Bpot- Talude & $\begin{array}{l}04^{\circ} 28.8002^{\prime} \mathrm{S} / \\
036^{\circ} 52.5554^{\prime} \mathrm{W}\end{array}$ & $\begin{array}{l}04^{\circ} 29.0224^{\prime} \mathrm{S} / \\
036^{\circ} 51.6292^{\prime} \mathrm{W}\end{array}$ & $915 \mathrm{~m}$ & $915 \mathrm{~m}$ & $1000 \mathrm{~m}$ & 4.20 & 34.53 \\
\hline MT 75-2 & 13.v.2011 & Bpot- Talude & $\begin{array}{l}04^{\circ} 28.9586^{\prime} \mathrm{S} / \\
036^{\circ} 51.0590^{\prime} \mathrm{W}\end{array}$ & $\begin{array}{l}04^{\circ} 28.7678^{\prime} \mathrm{S} / \\
036^{\circ} 52.9223^{\prime} \mathrm{W}\end{array}$ & $956 \mathrm{~m}$ & $965 \mathrm{~m}$ & $1000 \mathrm{~m}$ & 4.20 & 34.53 \\
\hline MT- 82 & 06.v.2011 & Bpot- Talude & $\begin{array}{l}04^{\circ} 33.7020^{\prime} \mathrm{S} / \\
036^{\circ} 14.7090^{\prime} \mathrm{W}\end{array}$ & $\begin{array}{l}04^{\circ} 34.4050^{\prime} \mathrm{S} / \\
036^{\circ} 12.9730^{\prime} \mathrm{W}\end{array}$ & $2094 \mathrm{~m}$ & $2068 \mathrm{~m}$ & $2000 \mathrm{~m}$ & 3.48 & 34.97 \\
\hline MT- 83 & 04.v.2011 & Bpot- Talude & $\begin{array}{l}04^{\circ} 28.3642^{\prime} \mathrm{S} / \\
036^{\circ} 24.7602^{\prime} \mathrm{W}\end{array}$ & $\begin{array}{l}04^{\circ} 29.4352^{\prime} \mathrm{S} / \\
036^{\circ} 24.1561^{\prime} \mathrm{W}\end{array}$ & $1950 \mathrm{~m}$ & $1880 \mathrm{~m}$ & $2000 \mathrm{~m}$ & 3.45 & 34.97 \\
\hline MT- 83-2 & 04.v.2011 & Bpot- Talude & $\begin{array}{l}04^{\circ} 27.0256^{\prime} \mathrm{S} / \\
036^{\circ} 25.6086^{\prime} \mathrm{W}\end{array}$ & $\begin{array}{l}04^{\circ} 24.4630^{\prime} \mathrm{S} / \\
036^{\circ} 27.1544^{\prime} \mathrm{W}\end{array}$ & $1896 \mathrm{~m}$ & $1931 \mathrm{~m}$ & $2000 \mathrm{~m}$ & 3.45 & 34.97 \\
\hline MT- 84 & 06.v.2011 & Bpot- Talude & $\begin{array}{l}04^{\circ} 25.8308^{\prime} \mathrm{S} / \\
036^{\circ} 37.3678^{\prime} \mathrm{W}\end{array}$ & $\begin{array}{l}04^{\circ} 25.8720^{\prime} \mathrm{S} / \\
036^{\circ} 36.4847^{\prime} \mathrm{W}\end{array}$ & $1964 \mathrm{~m}$ & 2019 m & $2000 \mathrm{~m}$ & 3.37 & 34.96 \\
\hline MT- 85 & 04.v.2011 & Bpot- Talude & $\begin{array}{l}04^{\circ} 21.3580^{\prime} \mathrm{S} / \\
036^{\circ} 44.2730^{\prime} \mathrm{W}\end{array}$ & $\begin{array}{l}04^{\circ} 22.0158^{\prime} \mathrm{S} / \\
036^{\circ} 43.2930^{\prime} \mathrm{W}\end{array}$ & $2057 \mathrm{~m}$ & $2025 \mathrm{~m}$ & $2000 \mathrm{~m}$ & 3.38 & 34.96 \\
\hline
\end{tabular}

Table 2. Minimum, mean and maximum values of biometric variables (TL and CL) in males, non-ovigerous females and ovigerous females from species of the genus Glyphocrangon A. Milne-Edwards, 1881 in the Potiguar Basin, northeastern Brazil.

\begin{tabular}{|c|c|c|c|c|c|c|}
\hline \multirow{2}{*}{ Species } & \multicolumn{3}{|c|}{ TL (mm) } & \multicolumn{3}{|c|}{ CL (mm) } \\
\hline & Min. & Mean & Max. & Min. & Mean & Max. \\
\hline \multicolumn{7}{|c|}{ Glyphocrangon aculeata } \\
\hline Males & 60.3 & 77.5 & 94.8 & 17.2 & 28.9 & 40.6 \\
\hline Females & 67.2 & 74.4 & 81.6 & 30.5 & 33.5 & 36.5 \\
\hline Ovigerous females & 97.5 & 108.3 & 119.1 & 22.8 & 35.2 & 47.6 \\
\hline \multicolumn{7}{|c|}{ Glyphocrangon alispina } \\
\hline Males & 36.1 & 53.8 & 71.5 & 9.1 & 19.2 & 29.3 \\
\hline Females & 44.6 & 60.1 & 75.7 & 8.3 & 18.9 & 29.6 \\
\hline
\end{tabular}


Table 2. Cont.

\begin{tabular}{|c|c|c|c|c|c|c|}
\hline \multirow{2}{*}{ Species } & \multicolumn{3}{|c|}{ TL (mm) } & \multicolumn{3}{|c|}{ CL (mm) } \\
\hline & Min. & Mean & Max. & Min. & Mean & Max. \\
\hline Ovigerous females & 44.8 & 64 & 83.2 & 13.5 & 19.8 & 26.1 \\
\hline \multicolumn{7}{|c|}{ Glyphocrangon longirostris } \\
\hline Males & 38.3 & 62.6 & 86.9 & 12.4 & 25.0 & 37.7 \\
\hline Females & 48.6 & 56.5 & 65.3 & 21.1 & 25.9 & 30.7 \\
\hline Ovigerous females & 63.6 & 80.2 & 96.8 & 14.1 & 27.9 & 41.8 \\
\hline \multicolumn{7}{|c|}{ Glyphocrangon sculpta } \\
\hline Ovigerous female & - & $98.2^{*}$ & - & - & $32.5^{*}$ & - \\
\hline \multicolumn{7}{|c|}{ Glyphocrangon spinicauda } \\
\hline Males & 55.5 & 69.3 & 83.2 & 11.0 & 23.0 & 35.1 \\
\hline Females & 54.6 & 68.3 & 82.0 & 10.7 & 22.0 & 33.3 \\
\hline Ovigerous females & 70.5 & 78.0 & 85.5 & 13.0 & 24.9 & 36.9 \\
\hline
\end{tabular}

Results

Order Decapoda Latreille, 1802

Infraorder Caridea Dana, 1852

Family Glyphocrangonidae Smith, 1884

Genus Glyphocrangon A. Milne-Edwards, 1881

Glyphocrangon aculeata A. Milne-Edwards, 1881

(Fig. 2A, B, Tab. 2)

Glyphocrangon aculeatum A. Milne-Edwards, 1881:

5. - A. Milne-Edwards, 1883, pl. 39.

Rhachocaris agassizii Smith, 1882: 43, pl. 5, fig. 2.

Glyphocrangon aculeata - Spence Bate, 1888: 521, pl.

94, fig. 1; - Holthuis, 1971: 323, fig. 10; - Coelho and Ramos, 1972: 156; - Chace, 1984: 6 (key);

- Ramos-Porto and Coelho, 1998: 342; - Komai, 2004a: 32, fig. 1a, b; - Coelho et al., 2006: 55; Serejo et al., 2007: 139; - Felder et al., 2009: 1061;

- Vázquez-Bader and Gracia, 2013: 371.

Material examined.60(IN); 21 (M), 37 (F), 2 (OF), Bpot-Talude \#AR 75, MOUFPE 15.203. 4 (IN); 1 (M), 3 (OF), Bpot-Talude \#MT 71, MOUFPE 15.149. 4 (IN); 4 (M), Bpot-Talude \#MT 72, MOUFPE 15.148. 1 (M), Bpot-Talude \#MT 72-2, MOUFPE 15.162. 2 (M), Bpot-Talude \#MT 73, MOUFPE 15.156.1 (IN); 1 (M), Bpot-Talude \#MT 73-2, MOUFPE 15.150. 17 (IN); 10 (M), 6 (F), 1 (OF), Bpot-Talude \#MT 74, MOUFPE 15.164. 5 (IN); 3 (M), 2 (OF), Bpot-Talude \#MT 74-2, MOUFPE 15.184. 2 (M), Bpot-Talude \#MT 75, MOUFPE 15.188. 1 (M), Bpot-Talude \#MT 75-2, MOUFPE 15.169.
Distribution. Western Atlantic: USA (North Carolina), Gulf of Mexico, Caribbean Sea, Venezuela, Brazil (Ceará and Rio Grande do Norte - Potiguar Basin, Pernambuco, Bahia, Espírito Santo, Rio de Janeiro, São Paulo) (Spence Bate, 1888; Komai, 2004a; Felder et al., 2009; this study).

Bathymetric distribution. The species has been recorded at depths of 443-1,760 m (Holthuis, 1971; Komai, 2004a; Felder et al., 2009; Vázquez-Bader and Gracia, 2013). In the present study, the species was recorded between depths of $908-1,110 \mathrm{~m}$.

Remarks. The examined specimens have the diagnostic characters of $G$. aculeata as described by Smith (1882), Holthuis (1971) and Komai (2004a). Glyphocrangon aculeata is easily recognized among the Atlantic species of the genus by the anterior fourth carina of the carapace forming a vertically compressed, acute lamina (wing-like spine).

Along the Brazilian coast, G. aculeata was first recorded by Spence Bate (1888) on the basis of material collected off Recife (state of Pernambuco), at a depth of 1,215 m. Komai (2004a) extended its distribution to the states of Bahia and Espírito Santo, between 707-1,760 $\mathrm{m}$ depth. The present record is the first from Potiguar Basin and fills a gap in the distribution of G. aculeata in the south Atlantic, suggesting that this species is much more widely distributed than currently assumed.

Females were more abundant and larger in size than compared to males (see Tab. 2). 


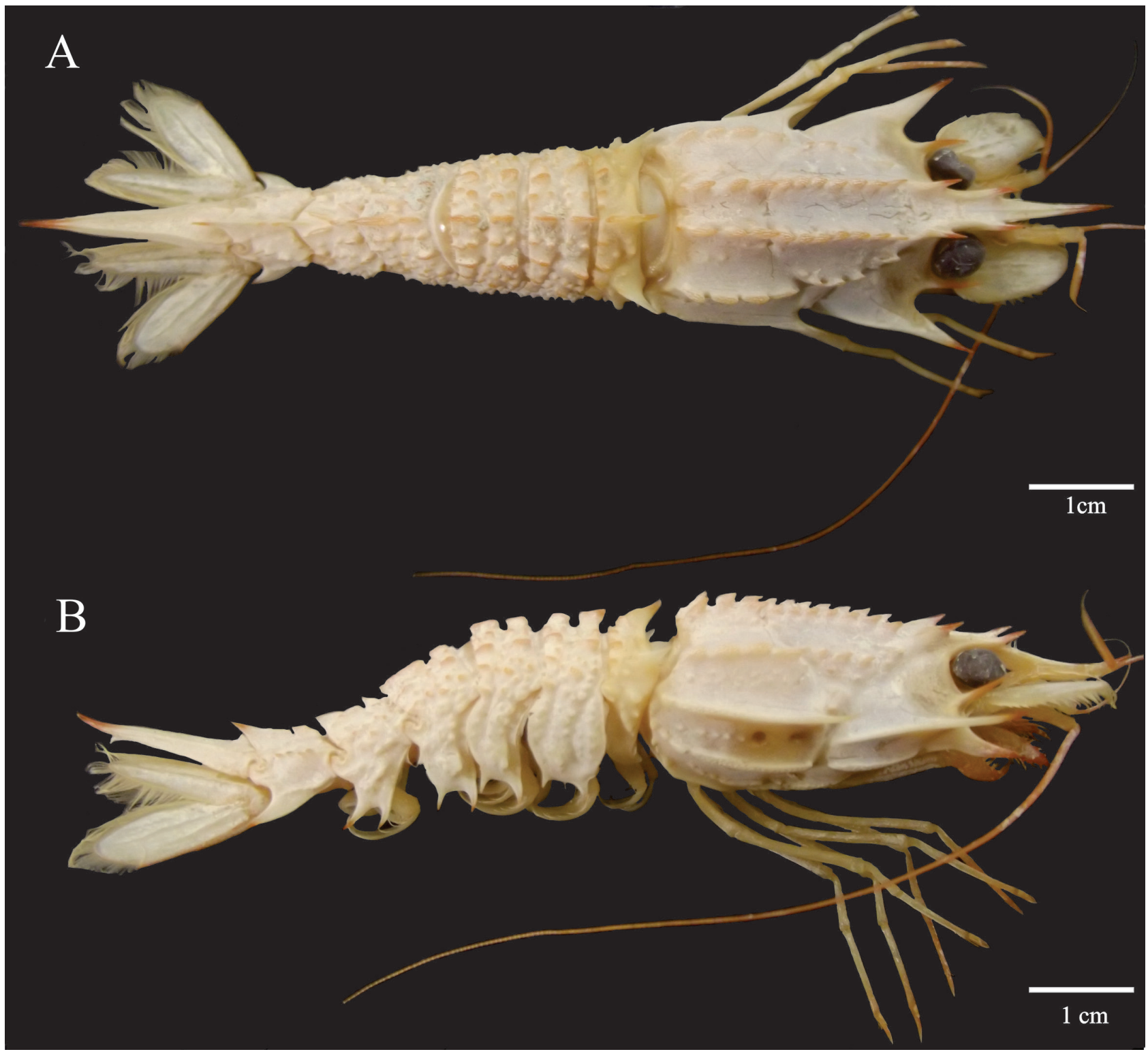

Figure 2. Glyphocrangon aculeata A. Milne-Edwards, 1881, dorsal (A) and lateral (B) views, male (TL-75.5 mm; Bpot-Talude MT\# 72-2; MOUFPE 15.162), northeastern Brazil.

\section{Glyphocrangon alispina Chace, 1939}

(Fig. 3A, B, Tab. 2)

Glyphocrangon alispina Chace, 1939: 39; - Pequegnat, 1970: 105; - Holthuis, 1971: 347, fig. 15; - Chace, 1984: 9 (Key); - Ramos-Porto et al., 2003: 98; Komai, 2004a, 33, fig. 1 c, d; - Coelho et al., 2006: 55; - Serejo et al., 2007:139; - Felder et al., 2009: 1061; - Vázquez-Bader and Gracia, 2013: 373.

Material examined. 2 (F), Bpot-Talude \#AR 75, MOUFPE 15211. 4 (IN); 2 (M), 2 (F), Bpot-Talude
\#MT 71-2, MOUFPE 15.166. 1 (M), Bpot-Talude \#MT 72-2, MOUFPE 15161. 4 (IN); 2 (M), 2 (F), Bpot-Talude \#MT 74, MOUFPE 15.163. 14 (IN); 6 (M), 2 (F), 6 (OF), Bpot-Talude \#MT 74-2, MOUFPE 15.186. 30 (IN); 17 (M), 9 (F), 4 (OF), Bpot-Talude \#MT 75, MOUFPE 15.190. 9 (IN); 6 (M), 2 (F), 1 (OF), Bpot-Talude \#MT 75-2, MOUFPE 15.182. 1 (OF), Bpot- Talude \#MT 82, MOUFPE 15.193. 1 (OF), Bpot-Talude \#MT 85, MOUFPE 15.187.

Distribution. Western Atlantic: USA (Florida), Gulf of Mexico (off Texas), northwestern Cuba (Matanzas 
Province, Santa Clara Province), off Nicaragua, Caribbean Sea (Virgin Islands), Guyana, Brazil (Amapá, Ceará and Rio Grande do Norte - Potiguar Basin, Bahia) (Holthuis, 1971; Komai, 2004a; this study).

Bathymetric distribution. In the state of Florida, $G$. alispina was found between depths of 548-1,865 m (Holthuis, 1971), whilst in the southwest and southeast of the Gulf of Mexico, there are records between depths of 671,9-1,144 m (Vázquez-Bader and Gracia, 2013). It has been recorded off the Brazilian coast between 421-900 m depths (Serejo et al., 2007). However, in this study, the species was found between depths of 908-2,094 m, thus extending its known bathymetric distribution.

Remarks. The specimens examined are in agreement with the original description of Chace (1939) and the subsequent redescription of Holthuis (1971). Holthuis (1971) mentioned that G. alispina is very similar to G. nobilis A. Milne-Edwards, 1881. Further, Komai (2004a) showed some differences between the species, such as: the size of the eye being larger in G. alispina than in G. nobilis, and the fourth and fifth pereopods more elongate in G. alispina than in G. nobilis. The material examined herein fits well with these states of characters.

Glyphocrangon alispina is restricted to the western Atlantic, ranging from the Gulf of Mexico to Brazil (Holthuis, 1971; Ramos-Porto et al., 2003; Komai, 2004a; Serejo et al., 2007; Vázquez-Bader and Gracia, 2013). Glyphocrangon alispina has been recorded on the Brazilian coast as far south as Bahia and the states of Espírito Santo and Rio de Janeiro (Campos Basin) (Komai, 2004a; Cardoso and Serejo, 2007; Serejo et al., 2007). Thus, the present record is the first from Potiguar basin.

Females were more abundant and larger in size when compared to males (see Tab. 2).

\section{Glyphocrangon longirostris (Smith, 1882)}

(Fig. 4A, B, Tab. 2)

Rhachocaris longirostris Smith, 1882: 51, pl. 5, fig. 1, pl. 6, fig. 1.

Glyphocrangon longirostris - Pequegnat, 1970: 106; -
Holthuis, 1971: 330, figs. 11-13; - Crosnier and Forest, 1973: 230, fig. 73a, b; - Chace, 1984: 8 (Key); - d'Udekem d'Acoz, 1999: 138; - Komai, 2004a: 35, fig. 2c, d; - Coelho et al., 2006: 55; Cardoso and Serejo, 2007: 40, fig. 1; - Serejo et al., 2007: 139; - Felder et al., 2009: 1061.

Material examined.69(IN); 12 (M), 8 (F), 49 (OF), Bpot-Talude \#AR 75, MOUFPE 15.210.2 (IN); 1 (F), 1 (OF), Bpot-Talude MT \#71-2, MOUFPE 15.167.6 (IN); 6 NI; 1 (M), 5 (OF), Bpot-Talude MT \#72-2, MOUFPE 15.159.4 (IN); 1 (M), 3 (OF), Bpot-Talude \#MT 73, MOUFPE 15.158. 16 (IN); 2 (M), 14 (OF), Bpot-Talude\#MT 74, MOUFPE 15.165. 8 (IN); 3 (M), 5 (OF), Bpot-Talude \#MT 74-2, MOUFPE 15.185. 5 (IN); 5 (OF), Bpot-Talude \#MT 75, MOUFPE 15.189. 3 (OF), Bpot-Talude \#MT 75-2, MOUFPE 15.183.3 (IN); 2 (M), 1 (F), Bpot-Talude \#MT 82, MOUFPE 15.168. 5 (IN); 3 (M), 2 (F), Bpot-Talude \#MT 83, MOUFPE 15.154. 14 (IN); 14 NI; 8 (M), 3 (F), 3 (OF), Bpot-Talude \#MT 83-2, MOUFPE 15.157. 2 (IN); 1 (M), 1 (F), Bpot-Talude \#MT 84, MOUFPE 15.171. 8 (IN); 6 (M), 2 (F), Bpot-Talude \#MT 85, MOUFPE 15.180.

Distribution. Western Atlantic:USA (Massachusetts), Brazil (Ceará and Rio Grande do Norte - Potiguar Basin, Bahia, Espírito Santo, Rio de Janeiro). Eastern Atlantic: Ireland to South Africa (Holthuis, 1971; Komai, 2004a; Serejo et al., 2007; this study).

Bathymetric distribution. The species was previously recorded in depths of 1,280-2,500 m (Holthuis, 1971). In southeastern Brazil it has been recorded between depths of 1,402-2,076 m (Serejo et al., 2007), with the current specimens found between the depths of 908-2,094 m.

Remarks. The present specimens adhere closely to the descriptions of Smith (1882), Holthuis (1971), Komai (2004a) and Cardoso and Serejo (2007). Glyphocrangon longirostris shares a character with $G$. nobilis and G. alispina, such as the anterior lateral carina of the carapace armed with only one terminal spine (Komai, 2004a). However, the absence of short setae on the carapace and abdomen, and the presence of a dorsal rugosity on the rostrum easily distinguish $G$. longirostris from those species. 


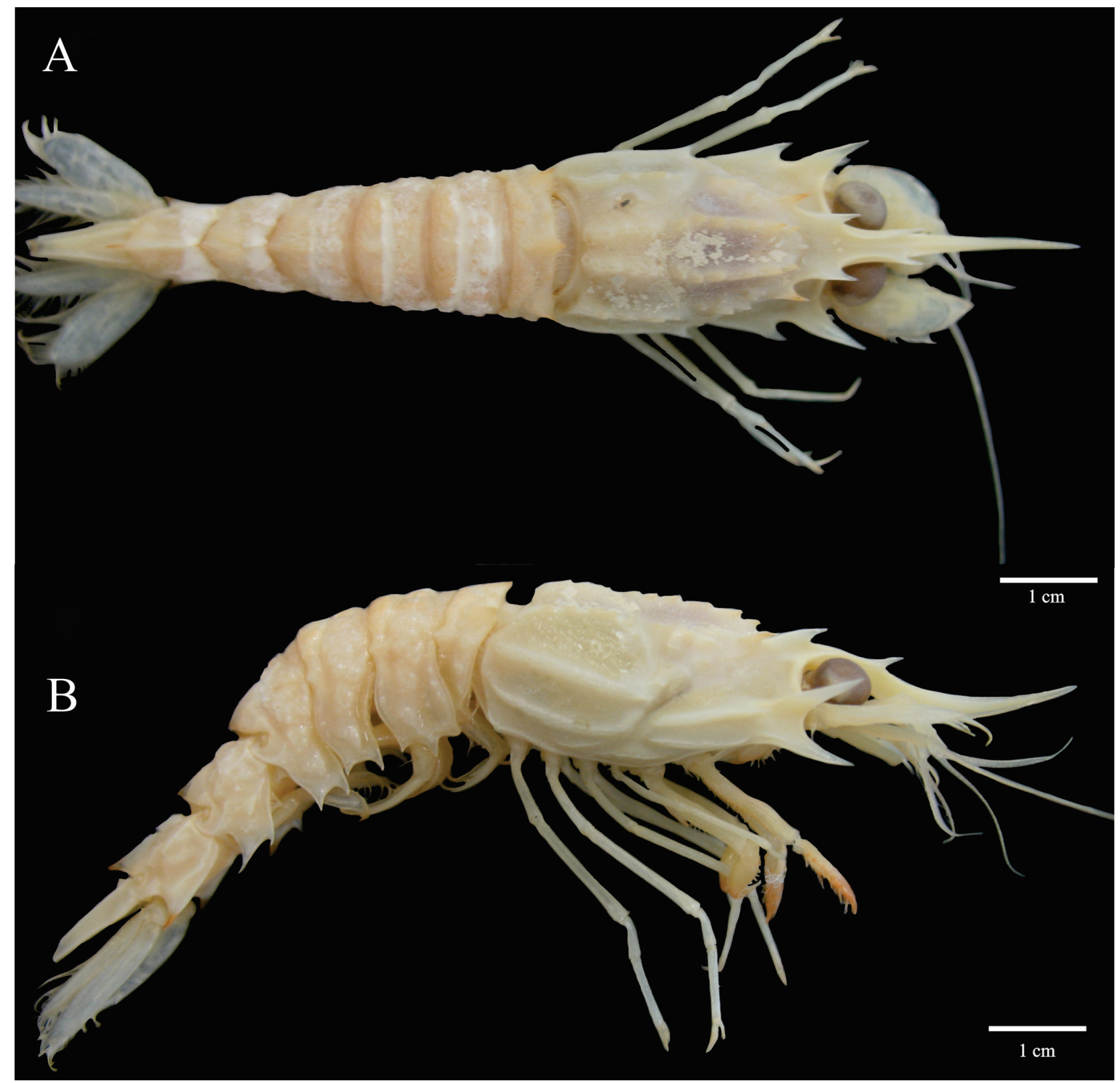

Figure 3. Glyphocrangon alispina Chace, 1939, dorsal (A) and lateral (B) views, male (TL-68.5 mm; Bpot-Talude MT\# 75-2; MOUFPE 15.182), northeastern Brazil.

Glyphocrangon longirostris has a wide geographical distribution in the Atlantic Ocean (both western and eastern) (Holthuis, 1971). However, this species was only recorded from Brazil rather recently by Komai (2004a). Later, Cardoso and Serejo (2007) recorded the species from the Campos Basin, off the coast of Rio de Janeiro. This study reports the occurrence of the species in the Potiguar Basin for the first time.

Females were more abundant and larger in size when compared to males (Tab. 2).

\section{Glyphocrangon sculpta (Smith, 1882)}

(Fig. 5A, B, Tab. 2)

Rhachocaris sculpta Smith, 1882: 49, pl. 5, fig. 3, pl. 6, fig. 3-3d.

Glyphocrangon sculptus - Smith, 1886: 608, 655, pl. 8, fig. 3, pl. 9, figs. 1, 2.

(?) Glyphocrangon sculptus - Pequegnat, 1970: 109.

Glyphocrangon sculpta - Holthuis, 1971: 279, figs. 2, 3; - Komai, 2004a: 39, fig. 4a, b; - Coelho et al., 2006: 55; - Serejo et al., 2007: 140. 


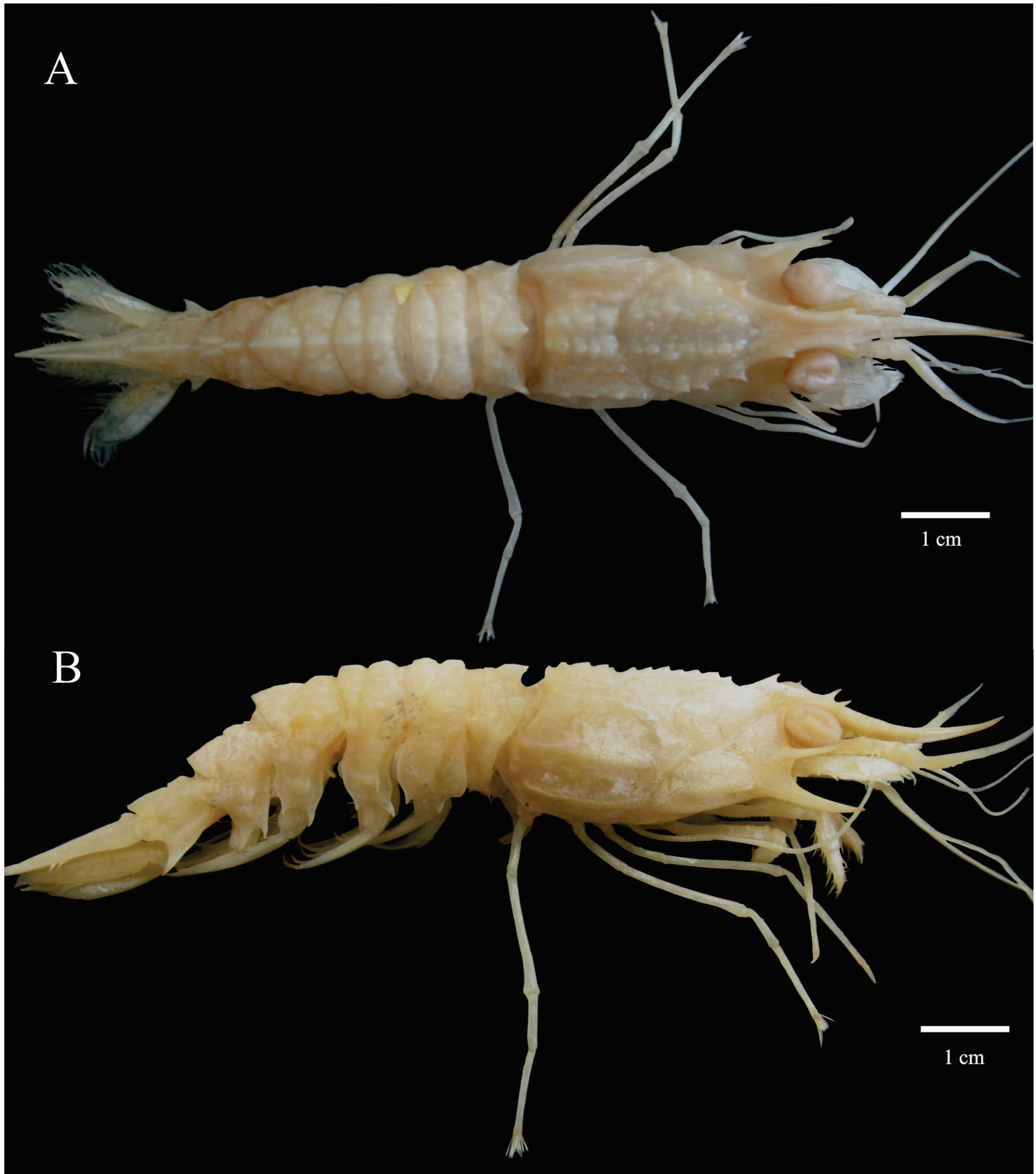

Figure 4. Glyphocrangon longirostris (Smith, 1882), dorsal (A) and lateral (B) views, male (TL-70 mm; Bpot-Talude MT \# 74; MOUFPE 15.165), northeastern Brazil.

Material examined. 1 (OF), Bpot-Talude \#MT 82, MOUFPE 15.193.

Distribution. Western Atlantic: East coast of USA (Massachusetts, Delaware), Caribbean Sea, Brazil (Potiguar Basin - Rio Grande do Norte, Bahia, Rio de Janeiro). Eastern Atlantic: from Iceland to Nigeria
(Holthuis, 1971; Komai, 2004a; 2010; this study).

Bathymetric distribution. Serejo et al. (2007) obtained specimens in Brazilian waters from 1,718$2,137 \mathrm{~m}$ depth. The present specimen came from exclusively at 2,094 $\mathrm{m}$. 


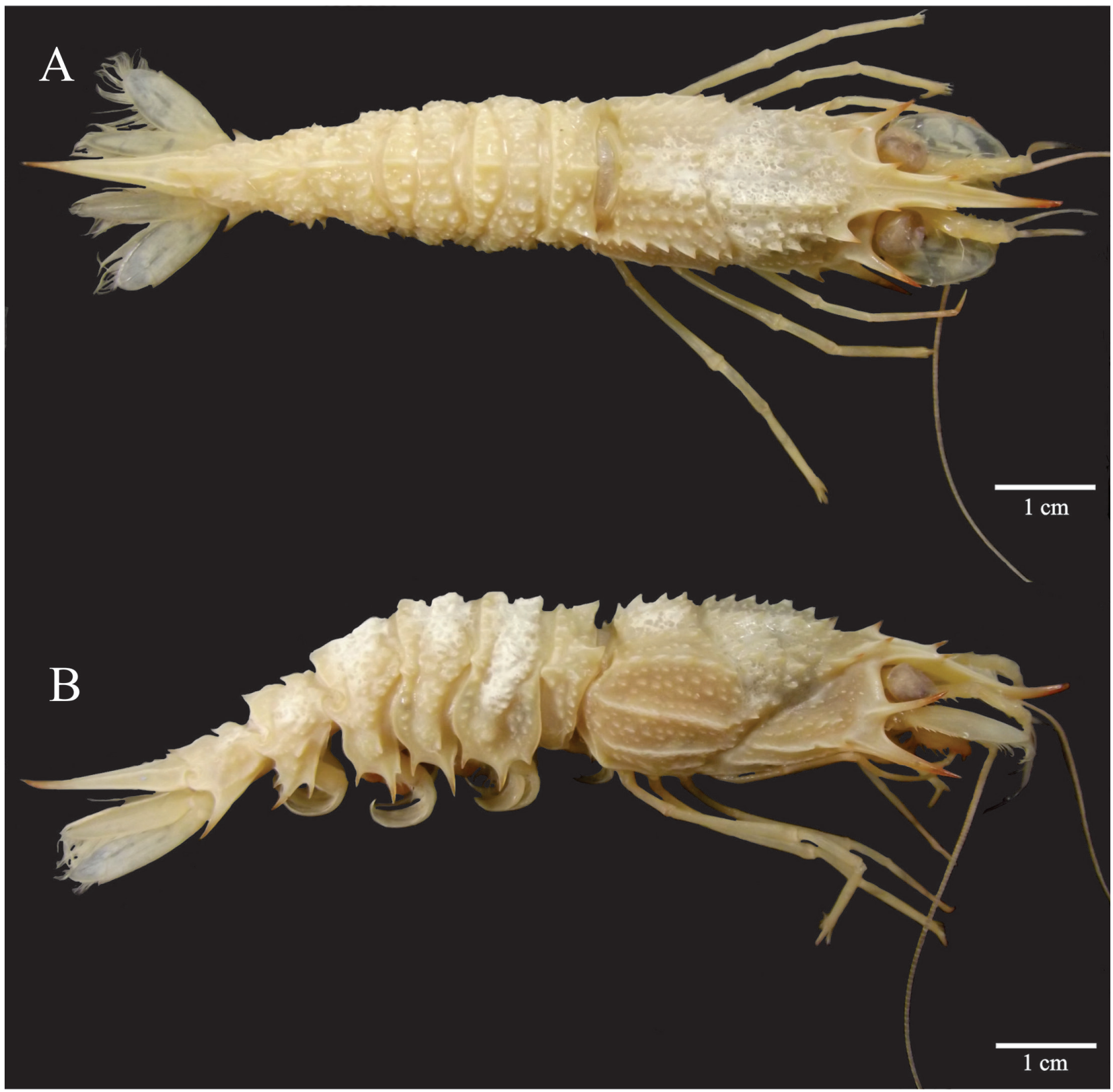

Figure 5. Glyphocrangon sculpta (Smith, 1882), dorsal (A) and lateral (B) views, ovigerous female (TL-98.2 mm; Bpot-Talude MT\# 82; MOUFPE 15.193), northeastern Brazil.

Remarks. Holthuis (1971) diagnosed G. sculpta as having three teeth on the fifth pleonal pleuron as does the present specimen. However, Pequegnat (1970) and Komai (2004b) stated that the armature is variable, sometimes having only two teeth. As shown by previous authors (Holthuis, 1971; Komai, 2004a), G. sculpta is easily recognizable among the Atlantic species by the spiny intercarinal spaces of the carapace, the clearly bidentate anterior fourth carina on the carapace and subcylindrical dactyli of the fourth and fifth pereopods, with the distal part horizontally cleft in females.
Glyphocrangon sculpta was assumed to exhibit amphi-Atlantic distribution (Komai, 2004a), but the southern African records of G. sculpta in Stebbing (1908), Barnard (1950) and Kensley (1968; 1981) were referred to Glyphocrangon africana Komai, 2010 by Komai (2010). Thus, the distribution records of G. sculpta in the eastern Atlantic range from the Bay of Biscay to Nigeria (Komai, 2010).

In the western Atlantic G. sculpta has a disjunct distribution, occurring along the east coast of the United States, between Massachusetts and Delaware, to the Caribbean (Holthuis, 1971) and in Brazil, off 
the coast Rio Grande do Norte (present study), Bahia and Rio de Janeiro (Komai, 2004a). The material studied herein is the second record of the species along the Brazilian coast, filling a gap in its geographical distribution.

\section{Glyphocrangon spinicauda A. Milne-Edwards, 1881} (Fig. 6A, B, Tab. 2)

Glyphocrangon spinicauda A. Milne-Edwards, 1881: 3 - Pequegnat, 1970: 110; - Holthuis, 1971: 295, figs. 6-7; - Coelho and Ramos, 1972: 157; - Chace, 1984: 7 (Key); - Forest and Holthuis, 1997: 56, pl. 40, fig. 1, 1a; - Ramos-Porto and Coelho, 1998: 342; - Ramos-Porto et al., 2000: 80; 2003: 99; Komai, 2004a: 40, fig. 4c, d; - Coelho et al., 2006: 55; - Serejo et al., 2007: 140; - Silva et al., 2007: 166; - Felder et al., 2009: 1061; - Vázquez-Bader and Gracia, 2013: 378.

Material examined. 132 (IN); 72 (M), 22 (F), 38 (OF), Bpot-Talude \#MT 61, MOUFPE 15.206. 8 (IN); 1 (F), 7 (OF), Bpot-Talude \#ARMT 62, MOUFPE 15.205. 26 (IN); 7 (M), 6 (F), 13 (OF), Bpot-Talude \#ARMT 65, MOUFPE 15.204. 20 (IN); 3 (F), 17 (OF), Bpot-Talude \#MT 65, MOUFPE 15.188. 36 (IN); 13 (M), 3 (F), 20 (OF), Bpot-Talude \#MT 64, MOUFPE 15.191. 112 (IN); 74 (M), 8 (F), 30 (OF), Bpot-Talude \#MT 65, MOUFPE 15.192.

Distribution. Western Atlantic: USA (east coast of Florida), Gulf of Mexico (Yucatan), northwest of Cuba, Caribbean Sea, south of Jamaica, Honduras, Nicaragua, off Guadeloupe, Dominica, Barbados, Brazil (Amapá, Pará, Maranhão, Ceará and Rio Grande do Norte Potiguar Basin, Bahia) (Holthuis, 1971; Ramos-Porto et al., 2000; Komai, 2004a; Felder et al., 2009; VázquezBader and Gracia, 2013; this study).

Bathymetric distribution. Lemaitre (1984) recorded the species in the Bahamas, between depths of 446$453 \mathrm{~m}$, whilst Holthuis (1971) recorded the species between 256-692 m, similar to the depths reported by Pequegnat (1970) and Ramos-Porto et al. (2000). In the present study, the species was found between the depths of $389-480 \mathrm{~m}$.
Remarks. The material examined corresponds to the descriptions in Holthuis (1971) and Komai (2004a). Komai (2004a: 41) assumed the first record of this species from Brazilian waters based on material collected by the project REVIZEE Score Central off Bahia coast. This author pointed out that G. spinicauda has been cited on an unpublished conference abstract record by Ramos-Porto \& Silva (2000). However, Komai (2004a) probably overlooked that Holthuis (1971) had already recorded this species in Brazil on the basis of eight ovigerous females collected at station of "Oregon" St. 2081 off the outfall of the Amazon River in the state of Pará. This record was cited by both Coelho and Ramos (1972) and Ramos-Porto and Coelho (1998). Also, Ramos-Porto et al. (2000; 2003) recorded this species in Amapá, Pará and Maranhão, based on the material collected by the project "REVIZEE/Pesca" in the northern region of Brazil. The present record is the first from the study area.

Females were more abundant and larger in size when compared to males (see Tab. 2).

\section{AbundanCE AND BATHYMETRIC DISTRIBUtION}

The species of Glyphocrangon were represented in three out of seven sampling stations in 2009, and 18 out of 31 stations in 2011 (ranging in depths between 400-2,000 m) (Tab. 1). A total of 810 shrimps were examined, belonging to five species: G. aculeata, $G$. alispina, G. longirostris, G. sculpta and G. spinicauda (Fig. 7). The most abundant species was G. spinicauda, which is usually found as a fishery by-catch in the north of Brazil (Ramos-Porto et al., 2000).

The specimens of G. aculeata were found only around 1,000 m, while G. sculpta was registered only at a depth of $2,000 \mathrm{~m}$. Both records are included in the bathymetric distribution limits known for the species (Komai, 2004a; Serejo et al., 2007; Vázquez-Bader and Gracia, 2013). The highest abundance of individuals of G. spinicauda was recorded around $400 \mathrm{~m}$ depth, although the previous records by Holthuis (1971) and Ramos-Porto et al. (2000) have registered this species deeper as far as $692 \mathrm{~m}$. The wide bathymetric range of G. alispina and G. longirostris has also been observed by Wenner (1978) and Komai (2004a), indicating a better tolerance to high variations of pressure, temperature and salinity compared to the others species of the genus. 


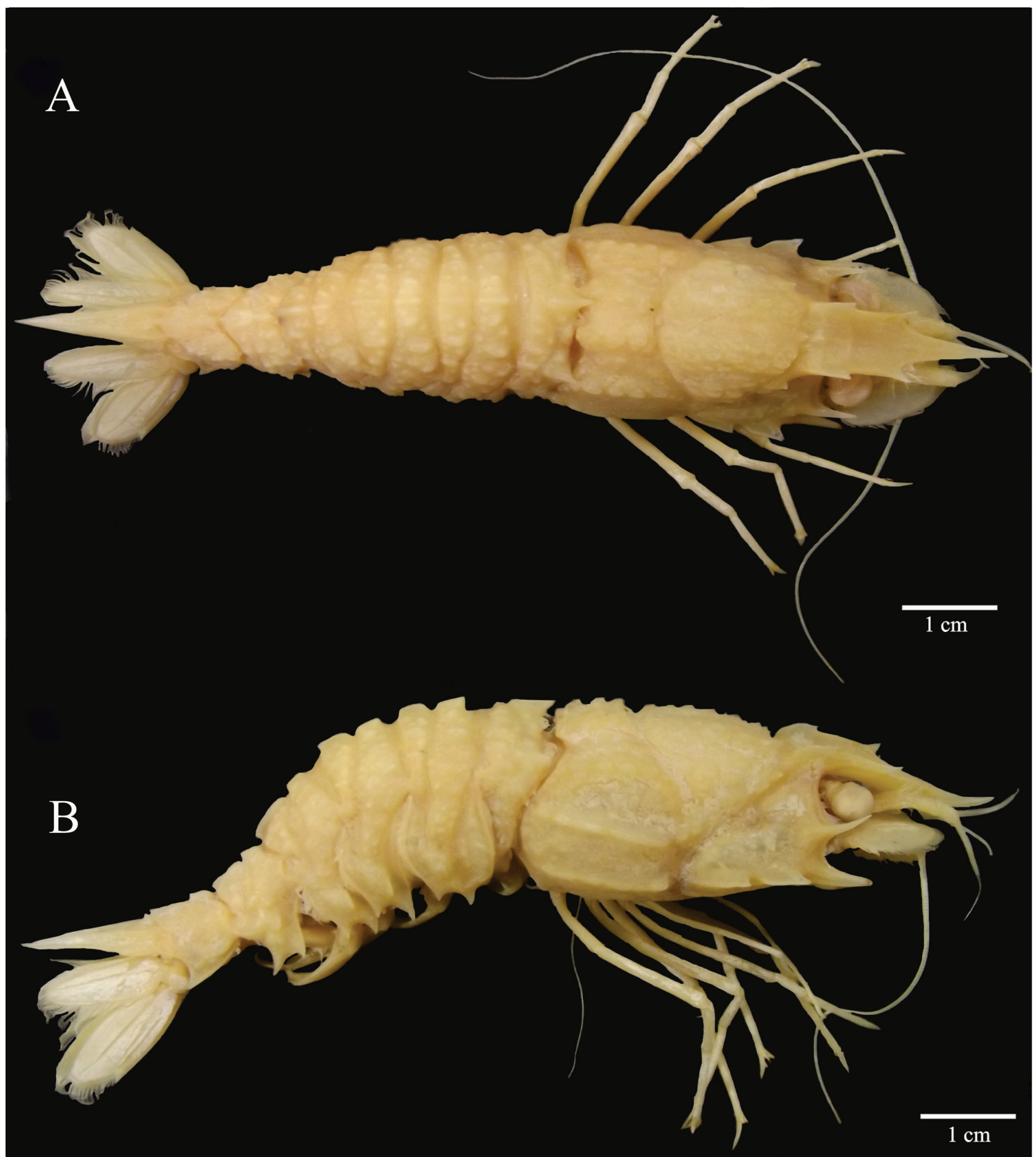

Figure 6. Glyphocrangon spinicauda A. Milne-Edwards, 1881, dorsal (A) and lateral (B) views, female (TL-62.5 mm; Bpot-Talude MT\# 65; MOUFPE 15.188), northeastern Brazil.

The larger proportion of ovigerous females was observed in four out of the five species reported in this study with ovigerous females being larger in size than non-ovigerous females and males. Thompson (1963) studied species of Glyphocrangon in the north Atlantic and suggested that spawning occurs all year long, due to a large proportion of sexually mature individuals in the population.

Thus, due to the low sampling effort in deep waters beyond the continental slope, the record of these species in the southwestern Atlantic (Potiguar Basin) is an important advancement to foster the knowledge 


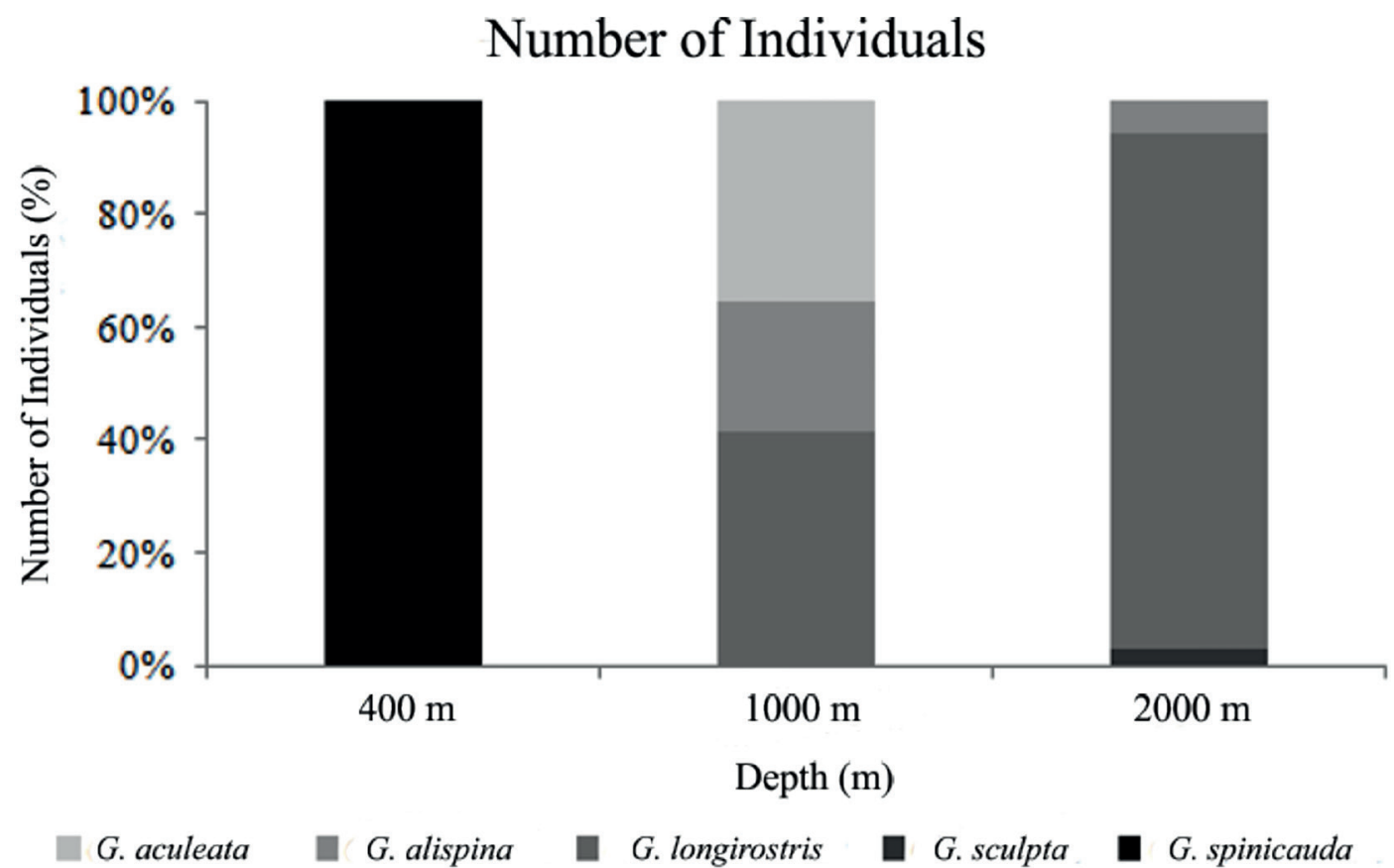

Figure 7. Number of specimens of Glyphocrangon A. Milne-Edwards, 1881 based on the depth in Potiguar Basin, northeastern Brazil.

of the geographic and bathymetric distribution of the deep-water shrimps of the genus Glyphocrangon. However, in Brazilian waters, the inventory of deep marine fauna is still far from complete, requiring further investigations to the knowledge of deep-sea biodiversity.

\section{ACKNOWLEDGEMENTS}

The first author thanks FACEPE for a postgraduate scholarship in Oceanography (protocol number IBPG1376-1.07/12), which supported this research, and Petróleo Brasileiro S.A. (Petrobrás) for the availability of the material for this study. The authors would like to thank the anonymous reviewers for their precious comments on this paper and also Dr. Sammy De Grave for the English review and valuable suggestions. This paper was presented at the $8^{\text {th }}$ International Crustacean Congress in Frankfurt, chaired by Dr. Michael Türkay (in memoriam).

\section{RefERENCES}

Anker, A.; Pachelle, P.P.G. and Tavares, M.D.S. 2014. Two new species and two new records of deep-water caridean shrimps from Brazil (Decapoda: Pandalidae, Palaemonidae, Crangonidae). Zootaxa, 3815: 263-278.
Alves-Júnior, F.A.; Araújo, M.S.L.C. and Souza-Filho, J.F. 2016 a. Distribution of two species of Nephropsis Wood-Mason, 1872 (Crustacea, Decapoda, Nephropidae) from northeastern Brazil. Zootaxa, 4114: 90-94.

Alves-Júnior, F.A.; Araújo, M.S.L.C.; Bertrand, A. and SouzaFilho, J.F. 2016b. First report of two deep-sea shrimps of the genus Acanthephyra A. Milne-Edwards, 1881 (Crustacea: Decapoda: Acanthephyridae) from southwestern Atlantic. Zootaxa, 4184: 193-200.

Barnard, K.H. 1950. Descriptive catalogue of South African decapod Crustacea (crabs and shrimps). Annals of the South African Museum, 38: 1-837.

Bertani, R.T.; Costa, I.G. and Matos, R.M.D. 1990. Evolução Tectono - sedimentar Estilo Estrutural e Habitat do Petróleo da Bacia Potiguar. p. 291-301. In: G.P. Raja Gabaglia and E.J. Milani (eds), Origem e evolução de bacias sedimentares. Rio de Janeiro, Petrobrás.

Brand, T. and Takeda, M. 1996. Glyphocrangon shrimps from the western Pacific collected by the R/V Hakuho-maru during the KH-72-1 cruise. Bulletin of the National Science Museum, Tokyo, 22: 263-281.

Burukovsky, R.N. 1990. Shrimps from the Sala-y-Gómez and Nazca Ridges. p. 187-217. In: A.N. Miranov and J.A. Rudjakov (eds), Plankton and benthos from the Nazca and Sala-y-Gómez submarine ridges. Transactions of the P.P. Shirshov Institute of Oceanology, 124.

Burukovsky, R.N. 2004. The Glyphocrangonidae (Crustacea, Decapoda) from Aden Gulf. p. 70-87. In: Nekotorie Problemi Gidrobiologii I Mikrobiologii. Kaliningradskii Goschdarstvennii Tekhicheskii Universitet [in Russian]. 
Cardoso, I.A. 2006. New record of Meningodora vesca (Caridea, Oplophoridae) to the southwestern Atlantic. Nauplius, 14: 1-7.

Cardoso, I.A. 2010a. First record of Parapontophilus longirostris Komai, 2008 (Caridea, Crangonidae) on Brazilian waters. Nauplius, 17: 29-35.

Cardoso, I.A. 2010b. First record of family Bathypalaemonellidae (Caridea: Decapoda) on Brazilian deep-sea coral reefs. Marine Biodiversity Records, 3: 1-4.

Cardoso, I.A. 2011a. New species of Plesionika Bate, 1888 (Crustacea, Decapoda, Pandalidae) from southwestern Atlantic. Zootaxa, 3089: 51-59.

Cardoso, I.A. 2011b. Three species of genus Plesionika Bate, 1888 (Caridea, Pandalidae) reported for the first time in the southwestern Atlantic. Cahiers de Biologie Marine, 52: 131-146.

Cardoso, I.A. 2013. The southwestern Atlantic Crangonidae (Caridea, Decapoda) including first records of two species. Cahiers de Biologie Marine, 54: 85-92.

Cardoso, I.A.; Falkenhaug, T. and Fernandes, L.F.L. 2014. Comparison between the shrimp species richness (Caridea and Dendrobranchiata, Decapoda, Crustacea) of the south and north mid Atlantic ridge. Brazilian Journal of Oceanography, 62: 47-56.

Cardoso, I.A. and Fransen, C.H.J.M. 2012. A new species of the deepwater shrimp genus Leontocaris (Hippolytidae: Caridea) from the South Mid-Atlantic Ridge. Journal of the Marine Biological Association of the United Kingdom, 92: 1083-1088.

Cardoso, I.A. and Serejo, C.S. 2007. Deep sea Caridea (Crustacea, Decapoda) from Campos Basin, RJ, Brazil. Brazilian Journal of Oceanography, 55: 39-50.

Chace, F.A. Jr. 1939. Preliminary descriptions of one new genus and seventeen new species of decapod and stomatopod Crustacea. Reports on the scientific results of the first Atlantis Expedition to the West Indies, under the joint auspices of the University of Havana and Harvard University. Memorias de la Sociedad Cubana de Historia Natural, 13: 31-54.

Chace, F.A. Jr. 1984. The caridean shrimps (Crustacea: Decapoda) of the Albatross Philippine Expedition, 1907-1910, Part 2: families Glyphocrangonidae and Crangonidae. Smithsonian Contributions to Zoology, 397: 1-63.

Coelho, P.A.; Almeida, A.O.; Souza-Filho, J.F.; Bezerra, L.E.A. and Giraldes, B.W. 2006. Diversity and distribution of the marine and estuarine shrimps (Dendrobranchiata, Stenopodidea and Caridea) from north and northeast Brazil. Zootaxa, 1221: 41-62.

Coelho, P.A. and Ramos, M.A. 1972. A constituição e a distribuição da fauna de decápodos do litoral leste da América do Sul entre as latitudes de $50^{\circ} \mathrm{N}$ e $39^{\circ} \mathrm{S}$. Trabalhos Oceanográficos da Universidade Federal de Pernambuco, 13: 133-236.

Crosnier, A. and Forest, J. 1973. Les crevettes profondes de l'Atlantique oriental tropical. Paris, ORSTOM, 409p. (Faune Tropicale, 19)

De Grave, S. and Fransen, C.H.J.M. 2011. Carideorum catalogus: the recent species of the dendrobranchiate, stenopodidean, procarididean and caridean shrimps (Crustacea: Decapoda). Zoologische Mededelingen, 85: 195-589.

D’Incao, F. 1998. Malacostraca. Eucarida. Dendrobranchiata. p. 311-321. In: P.S. Young (ed), Catalogue of Crustacea of Brazil. Rio de Janeiro, Museu Nacional.
d'Udekem d'Acoz, C. 1999. Inventaire et distribution des crustacés décapodes de l'Atlantique nord-oriental, de la Médiranée et des eaux continentales adjacentes au nord de $25^{\circ} \mathrm{N}$. Collection Patrimoines Naturels, 40: 1-383.

Felder, D.L.; Álvarez, F.; Goy, J.W. and Lemaitre, R. 2009. Decapoda (Crustacea) of the Gulf of Mexico, with comments on the Amphionidacea. p. 1019-1104. In: D.L. Felder and D.K. Camp (eds), Gulf of Mexico Origin, Waters, and Biota Volume 1, Biodiversity. Texas A\&M University Press, College Station.

Forest, J. and Holthuis, L.B. 1997. A. Milne-Edwards recueil de figures de Crustacés nouveaux ou peu connus, 1883. New facsimile edition with comments and annotations. Leiden, Backhuys Publishers, 128p.

Hendrickx, M.E. 2010. A new species of Glyphocrangon (Decapoda: Caridea: Glyphocrangonidae) from off the coast of western Mexico. Zootaxa, 2372: 358-366.

Holthuis, L.B. 1971. The Atlantic shrimps of the deep-sea genus Glyphocrangon A. Milne-Edwards, 1881. Bulletin of Marine Science, 21: 267-373.

Kensley, B.F. 1968. Deep sea decapod Crustacea from west of Cape Point, South Africa. Annals of the South African Museum, 50: 283-323.

Kensley, B. 1981. On the zoogeography of southern African decapod Crustacea, with a distributional check list of the species. Smithsonian Contributions to Zoology, 338: 1-64.

Kensley, B.F.; Tranter, H.A. and Griffin, D.J.G. 1987. Deep-water decapods Crustacea from eastern Australia (Penaeidea and Caridea). Records of the Australian Museum, 39: 263- 331.

Komai, T. 2004a. Deep-sea shrimps of the genus Glyphocrangon A. Milne-Edwards (Crustacea, Decapoda, Caridea, Glyphocrangonidae) from off southeastern coast of Brazil collected during the Revizee program. Arquivos do Museu Nacional, 62: 31-44.

Komai, T. 2004b. Crustacea Decapoda: A review of the IndoWest Pacific species of the genus Glyphocrangon A. Milne Edwards, 1881 (except the G. caeca species group) (Crustacea: Decapoda: Caridea: Glyphocrangonidae).p. 375-610. In: B. Marshall and R.B. Forges (eds), Tropical Deep-Sea Benthos Volume 23. Mémoires du Muséum National d'Histoire Naturelle, 191.

Komai, T. 2005. A distinctive new species of the deep-water shrimp genus Glyphocrangon A. Milne-Edwards (Crustacea: Decapoda: Caridea: Glyphocrangonidae). Records of the Western Australian Museum, 22: 253-258.

Komai, T. 2006. Revision of the Glyphocrangon caeca species group (Crustacea, Decapoda, Glyphocrangonidae). p. 243264. In: R.B. Forges and J.L. Justine (eds), Tropical DeepSea Benthos Volume 24. Mémoires du Muséum National d'Histoire Naturelle, 193.

Komai, T. 2007. A new species of Glyphocrangon (Crustacea, Decapoda, Caridea, Glyphocrangonidae) from the Austral Islands, French Polynesia. Zoosystema, 29: 565-573.

Komai, T. 2010. A new species of the deep-sea shrimp genus Glyphocrangon A. Milne-Edwards (Crustacea: Decapoda: Caridea: Glyphocrangonidae) from the southeastern Atlantic off southern Africa. African Natural History, 6: 83-90. 
Komai, T. 2011. Further records of deep-sea shrimps of the genus Glyphocrangon (Crustacea: Decapoda: Caridea: Glyphocrangonidae) from the southwestern Pacific, with descriptions of two new species. Species Diversity, 16: 113-135.

Komai, T. and Chan, T.Y. 2008. Further records of deep-sea shrimps of the genus Glyphocrangon A. Milne-Edwards, 1881 (Crustacea: Decapoda: Caridea) from the Philippines, with descriptions of three new species. Raffles Bulletin of Zoology, Supplement, 19: 39-62.

Komai, T. and Chan, T.Y. 2013. New records of Glyphocrangon A. Milne-Edwards, 1881 (Crustacea, Decapoda, Caridea, Glyphocrangonidae) from recent French expeditions off the Mozambique channel and Papua New Guinea, with description of one new species. p. 107-128. In: S.T. Ahyong; T.Y. Chan; L. Corbari, and P.K.L. Ng (eds), Tropical deepsea benthos, Volume 27. Mémoires du Muséum national d'Histoire naturelle, 204.

Komai, T. and Takeuchi, I. 1994. Glyphocrangon fimbriata, a new species of caridean shrimp (Crustacea: Decapoda: Glyphocrangonidae) from Sio Guyot, mid-Pacific mountains. Proceedings of the Biological Society of Washington, 107: 458464.

Lemaitre, R. 1984. Decapod crustaceans from Cay Sal Bank, Bahamas, with notes on their zoogeographic affinities. Journal of Crustacean Biology, 4: 425-447.

Milne-Edwards, A. 1881. Description de quelques crustacés macroures provenant des grandes profondeurs de la mer des Antilles. Annales des Sciences Naturelles, Zoologie et Biologie Animale, 6: 1-16.

Milne-Edwards, A. 1883. Recueil de figures de Crustacés nouveaux ou peu connus. Paris, 3p., 44 plates.

Pequegnat, L. 1970. Deep-sea caridean shrimps with descriptions of six new species. p. 59-123. In: W.E. Pequegnat and F.A. Jr. Chace (eds), Contributions on the Biology of the Gulf of Mexico. Houston, Texas A. \& M. University Oceanographic Studies.

Ramos-Porto, M. and Coelho, P.A. 1998. Malacostraca - Eucarida. Caridea (Alpheoidea excluded). p. 325-350. In: P.S. Young (ed), Catalogue of Crustacea of Brazil. Rio de Janeiro, Museu Nacional.

Ramos-Porto, M.; Muniz, A.P.M.; Silva, K.C.A.; Cintra, I.H.A. and Viana, G.F.S. 2003. Camarões da subordem Pleocyemata Burkenroad, 1963 capturados durante pescarias experimentais para o programa REVIZEE/norte (Crustacea, Decapoda). Boletim Técnico Científico do Cepnor, 3: 77-106.

Ramos-Porto, M. and Silva, K.C.A. 1998. Camarões de profundidade coletados na costa norte do Brasil (Crustacea: Penaeidea e Caridea), p. 101. In: XXII Congresso Brasileiro de Zoologia, Recife, Brazil.

Ramos-Porto, M.; Silva, K.C.A.; Viana, G.F.S. and Cintra, I.H.A. 2000. Camarões de profundidade coletados no norte do Brasil (Crustacea: Penaeidea e Caridea). Trabalhos Oceanográficos da Universidade Federal de Pernambuco, 28: 71-85.
Rego, A. and Cardoso, I.A. 2010. Taxonomy and distribution of shrimps genus Heterocarpus A. Milne-Edwards, 1881 collected on the Brazilian slope by Program REVIZEE-Central Score. Nauplius, 18: 117-128.

Rice, A.L. 1981. The status of Glyphocrangon rimapes Bate, 1888 (Crustacea, Decapoda, Glyphocrangonidae). Bulletin of the British Museum of Natural History (Zoology), 40: 275-285.

Serejo, C.S.; Young, P.S.; Cardoso, I.C.; Tavares, C.; Rodrigues, C. and Almeida, T.C. 2007. Abundância, diversidade e zonação dos crustáceos no talude da costa central do Brasil (11 ${ }^{\circ}$ $22^{\circ} \mathrm{S}$ ) coletados pelo Programa REVIZEE/Score Central: prospecção pesqueira. p. 133-162. In: P.A.S. Costa; G. Olavo and A.S. Martins (eds), Biodiversidade da fauna marinha profunda na costa central brasileira. Rio de Janeiro, Museu Nacional.

Silva, K.C.A.; Cintra, I.H.A.; Ramos-Porto, M. and Viana, G.F.S. 2007. Camarões da plataforma continental do estado do Maranhão (Crustacea, Decapoda) coletados durante o programa Revizee/norte. Boletim Técnico Científico do Cepnor, 7(1): 163-172.

Smith, S.I. 1882. Reports on the results of dredging, under the supervision of Alexander Agassiz, on the east coast of the United States, during the summer of 1880 , by the U. S. Coast Survey Steamer "Blake," Commander J.R. Bartlett, U.S.N., Commanding. XVII. Report on the Crustacea. Part I. Decapoda. Bulletin of the Museum of Comparative Zoology, 10: 1-108, pls. 1-16.

Smith, S.I. 1884. Report on the decapod Crustacea of the 'Albatross' dredgings off the east coast of the United States in 1883. Reports of the United States Fisheries Commission, 10: 345-426, pls. 1-10.

Smith, S.I. 1886. Report on the decapod Crustacea of the Albatross dredgings off the east coast of United States, during the summer and autumn of 1884 . Report of the Commissioner for 1885. United States Comission of Fish and Fisheries, 13: 605-706, pls. 1-20.

Spence Bate, C.S. 1888. Report on the Crustacea Macrura collected by H.M.S. Challenger during the Years 1873-76. In: J. Murray (ed.) Zoology. Report on the Scientific Results of the Voyage of H.M.S. Challenger During the Years 1873-76 Under the Command of Captain George S. Nares, R.N., F.R.S. and the Late Captain Frank Tourle Thomson, R.N. Wyville Thomson, C. and J. Murray (series eds.) Vol. 24. Edinburgh, Neill and Company. pp. i-xc, 1-942, pls. 1-157.

Stebbing, T.R.R. 1908. South African Crustacea, Part 4. Marine investigations in South Africa. Annals of the South African Museum, 6: 1-96, pls. 27-40.

Thompson, J.R. 1963. The bathyalbenthic caridean shrimps of the southwestern north Atlantic. Duke University, Ph.D Dissertation. 504 p. [Unpublished]

Vázquez-Bader, A.R. and Gracia, A. 2013. Crangonidae and Glyphocrangonidae (Decapoda; Caridea) of the southern Gulf of Mexico. Zootaxa, 3669: 367-383.

Wenner, E.W. 1978. Comparative biology of four species of glyphocrangonid and crangonid shrimp from the continental slope of the middle Atlantic Bight. Canadian Journal of Zoology, 56: 1052-1065. 